\title{
Risk factors for surgical site infections in obstetrics: a retrospective study in an Ethiopian referral hospital
}

Teshager Mamo ${ }^{1}$, Tilaye Workneh Abebe ${ }^{2}$, Tesfaye Yitna Chichiabellu ${ }^{3}$ and Antehun Alemayehu Anjulo ${ }^{*^{*}}$

\begin{abstract}
Background: Pregnant women are at risk of infection during labor and delivery. Infection in obstetrics accounts for the second most common cause of maternal mortality next to post partum hemorrhage. Knowing the prevalence and associated risk factors would help to undertake optimal precautions and standard surgical techniques to reduce surgical site infection which poses increased hospital cost and total hospital stay of the patients.

Method: Facility based retrospective observational study design was carried out purposively to assess the prevalence of surgical site infections and associated risk factors among mothers who had delivery related surgery at obstetric ward of Assela teaching referral hospital from April, 23, 2015 to September 5, 2015. A total of 384 women who had surgery for delivery were included in the study. The risk associated with SSIs was assessed by multivariate regression logistic analysis.

Results: The age of the women ranged from 17 to 40 years with the mean age of $26( \pm 5)$ years. The rate of surgical site infection was 9.4\%(36/384). The risk factors for surgical site infection were age less than 19 (OR=3.5, 95\%Cl 1.17-10.01), preterm gestation age $(\mathrm{OR}=4.22595 \% \mathrm{Cl} 1.254-14.238)$, duration of labor $\geq 24 \mathrm{~h}(\mathrm{OR}=2.21995 \% \mathrm{Cl} .054-4.670)$, duration of rupture of membrane $\geq 12 \mathrm{~h}(\mathrm{OR}=5.99,95 \% \mathrm{Cl} 2.75-13.02)$, chorioamnionitis $(\mathrm{OR}=9.743,95 \% \mathrm{Cl} 3.077-30.848)$, vertical skin incision $(\mathrm{OR}=4,95 \% \mathrm{Cl}$ 1.709-13.322), pre operation Hematocrit $(\mathrm{OR}=6.4,95 \% \mathrm{Cl} 1.021-40.137)$, perioperative blood transfusion $(\mathrm{OR}=6.75,95 \% \mathrm{Cl} 2.47,18.49)$, abdominal hysterectomy $(\mathrm{OR}=7.9,95 \% \mathrm{Cl} 1.698-36.960)$, and diabetic mellitus (OR $=3.7,95 \% \mathrm{Cl} 1.112-12.519)$.

Conclusions: Obstetric ward of Assela teaching referral hospital are encouraged to use properly WHO surgical safety checklist and examine how to sensibly integrate these essential safety steps into their normal operative workflow. Prophylactic antibiotic administration should be provided within one hour before the surgical incision or within two hours if the patient is receiving vancomycin or floroquinolones.
\end{abstract}

Keywords: Surgical site infection, Risk factors

\section{Background}

Pregnant women are at risk of infection during labor and delivery; most infections of the female pelvic organs occur when normal flora of the female genital or gastrointestinal tract contaminate the normally sterile amniotic fluid and uterus [1]. Infection in obstetrics accounts for the second most common cause of maternal mortality next to post partum hemorrhage [2].

\footnotetext{
* Correspondence: Antehunalemayehu@gmail.com

${ }^{4}$ Department of Medical Laboratory, School of Medicine, College of Health sciences and Medicine, Wolaita Sodo University, P.O. Box: 138, Wolaita Sodo, Ethiopia

Full list of author information is available at the end of the article
}

Centers for Disease Control and Prevention's (CDC's) and National Healthcare Safety Network

(NHSN) categorized Surgical Site Infections (SSIs) in to 3 groups. According to this classification Organ/ space SSIs involve any part of the anatomy and that must develop within 30 days after procedures (e.g. organ/space) but does not include incision body wall layers that was opened or manipulated during an operation. Incision SSIs involving only skin and subcutaneous tissue are grouped as superficial incision SSIs and incision involving the deeper soft tissue classified as deep incision SSI [3-6]. 
SSIs are the most common nosocomial infections, accounting for $38 \%$ of hospital acquired infections [7] and each SSI demanding the cost of $\$ 2739$ in USA $[1,8]$. Infections prolonged hospitalization from 1.5 to 16.6 days [9-12]. Studies showed that the prevalence of SSI after cesarean section varied from 3\% to $15 \%$, depending on the surveillance methods used to identify infections, the patient population, and the use of antibiotic prophylaxis [13]. It is highly prevalent and more serious in developing countries; especially in sub-Saharan Africa; twice or three times higher than developed countries $[1,14,15]$.

When we see the distribution of SSIs in Africa; the cumulative incidence in Algerian was 11.9\% in 2001, 9.4\% among women who underwent caesarean section in Ugandan, 23.6 per 100 operations in Nigeria [8], In Ethiopia, there was only one study done in Jimma University Specialized Hospital, Southwest Ethiopia. According to this study the prevalence of SSI following cesarean Section accounted for 66 (75.0\%) [16].

According to previous report, maternal morbidity related to infections after cesarean section was eight-fold higher than that of vaginal delivery [10-12]. Cesarean section is one of the most commonly performed obstetrical surgical procedures in Assela teaching hospital, the rate of cesarean section has increased from approximately $3 \%$ in the 1994 to more than $15 \%$ recently. Knowing the prevalence of the problem and associated risk factors would help to undertake optimal precautions and standard surgical techniques to reduce SSI which poses increased hospital cost and total hospital stay of the patients. This study intended to assess the prevalence of SSI and associated risk factors.

\section{Methods}

\section{Study area}

The study was conducted in Assela town. Assela town is located in Oromia region, $170 \mathrm{~km}$ far from Addis Ababa. The hospital has been serving 3.5 million populations and in Arsi and the nearby zones; have 331 beds in total. Department of Obstetrics and Gynecology has two wards. Obstetrics ward has 49 bed and Gyn. Ward 29 bed. $\mathrm{MCH}$ and family planning clinic, and two Gynecologic OPD. It has three consultant Obstetricians \& Gynecologists, six physicians, seventeen midwives and eight clinical nurses. Reviewing the registration log book, there were 3618 obstetric cases among this 945 cesarean section and 1 destructive delivery under direct vision in the last one year.

\section{Study design and period}

Facility based retrospective observational study design was carried out purposively to assess the prevalence of surgical site infections and associated risk factors among mothers who had delivery related surgery at obstetric ward of Assela teaching referral hospital from April, 23, 2015 to September 5, 2015 till to reach the calculated sample size.

\section{Population \\ Source population}

All women who had major surgery related delivery at Assela teaching hospital.

\section{Study population}

All women who had major surgery related delivery in obstetrics ward at Assela teaching hospital during the study period.

\section{Inclusion criteria}

- All 384 women who had surgery related to delivery and who developed surgical site infections in obstetrics ward at Assela teaching hospital

\section{Exclusive criteria}

- Patients who died before the third post operative days were excluded, because SSIs cannot be diagnosed before three days of operative procedure.

- Women referred from other health care facilities for the diagnosis of SSIs

- Infection associate with minor procedures like episiotomy and stitch site infection

\section{Sample size and sampling procedures}

A single population proportion formula was used to attain 95\% confidence interval, 50\% prevalence of SSIs and $5 \%$ margin of error were taken. The calculated sample size was 384. Then, study subjects were selected using consecutive sampling technique.

\section{Data collection instrument and procedure}

A semi-structured interviewer administered data collection format was used to collect data for those who developed surgical site infections both from the records and from the study participants. Questionnaire was adopted from similar study and modified to the context of study area after reviewing relevant literatures [16]. It includes basic demographic details and risk factors associated with surgical site infection. Checklist was used to collect data from the medical records. Laboratory reporting format was used for hemoglobin measurement.

\section{Data processing and analysis}

After individual data were scrutinized thoroughly for completeness, coding was done accordingly and the data were subsequently fed in to SPSS version 20.0 for analysis. After descriptive analysis was done; association between dependent 
variable and the risk factors was determined by comparing each group separately with univariate analysis. On the basis of the results in the univariate analysis, statistically significant variables were included in the multivariate model. Multivariable regression was used to adjust or control the possible confounding factors and to identify risk factors of SSIs. Odd ratio was used with $95 \%$ confidence interval to identify factor significant associated with SSI. The cut point for Statistical significance was $P<0.05$.

\section{Result}

\section{Socio-demographic characteristics of study population}

Overall, 1399 mothers visited the hospital related to delivery and 390 underwent operation during the study period. Three hundred eighty four patients were enrolled in the study ( 5 patients refused to participate, and 1 patient died immediately after operation). The age of the women ranged from 15 to 40 years with the mean age of $26( \pm 5)$ years. Majority of women $309(80.5 \%)$ were in the age group of 20-34 years. About 218(56.8\%) were resident of rural area and the rest 166(43.2\%) were from urban area. Regarding ethnicity; 219(67.4\%) were Oromo. Majority of women were Muslim in religion; 184(47.9\%) followed by orthodox Christian and protestant. With regard to job, 225(58.6\%) of the study participants were House wife. Concerning the educational status of the participants; majority $77(20 \%)$ were illiterate. In this study 381(99.7\%) were married in terms of marital status. Majority of the study participant family the monthly income was <1000birr or 48.5 dollars; which accounts $175(45.6 \%)$ (Table 1$)$.

\section{Types of surgical procedure}

A total of $370(88.9 \%)$ underwent cesarean section. However 330 out of $370(89.6 \%)$ were emergency cesarean

Table 1 Socio-demographic characteristics' of women having surgery for delivery in obstetrics of Assela Teaching Hospital, April, 23, 2015 to September 5, 2015

\begin{tabular}{|c|c|c|c|}
\hline Variable & & Frequency & Percent \\
\hline \multirow[t]{3}{*}{ Age } & $\leq 19$ & 23 & 13.9 \\
\hline & $20-34$ & 309 & 63.9 \\
\hline & $\geq 35$ & 52 & 22.2 \\
\hline \multirow[t]{2}{*}{ Address } & Urban & 166 & 47.2 \\
\hline & Rural & 218 & 52.8 \\
\hline \multirow[t]{5}{*}{ Ethnicity } & Oromo & 259 & 67.4 \\
\hline & Amhara & 62 & 16.1 \\
\hline & Tigrie & 32 & 8.3 \\
\hline & Guragie & 20 & 5.2 \\
\hline & Other & 11 & 2.9 \\
\hline \multirow[t]{4}{*}{ Religion } & Orthodox Christian & 136 & 35.4 \\
\hline & Protestant & 61 & 15.9 \\
\hline & Muslim & 184 & 47.9 \\
\hline & Other & 3 & 0.8 \\
\hline \multirow[t]{4}{*}{ Occupation } & House wife & 225 & 58.6 \\
\hline & Civil servant & 100 & 26 \\
\hline & Farmer & 3 & 8 \\
\hline & Merchant & 56 & 14.6 \\
\hline \multirow[t]{5}{*}{ Educational Status } & Illiterate & 77 & 20.1 \\
\hline & Read \&Write Only & 54 & 13.8 \\
\hline & Grade 1-8 & 68 & 17.7 \\
\hline & Grade 9-12 & 98 & 25.5 \\
\hline & Above grade 12 & 88 & 22.9 \\
\hline \multirow[t]{2}{*}{ Marital Status } & Married & 383 & 99.7 \\
\hline & Divorced & 1 & 0.3 \\
\hline \multirow[t]{3}{*}{ Average monthly income of Family } & Less than 1000 & 175 & 45.6 \\
\hline & 1001-3999 & 107 & 27.9 \\
\hline & Greater than 4000 & 102 & 26.6 \\
\hline
\end{tabular}


section and the remaining $40(10.4 \%)$ were underwent elective cesarean sections (Table 2). Moreover, 9(8.3\%) underwent abdominal hysterectomy and only 5(2.8\%) underwent uterine repair. Majority of the operations were emergency cases.

\section{Magnitude of SSI}

A total of 36 out of 384 (9.4\%) developed SSIs following major surgery related to delivery in obstetrics ward at Assela teaching referral hospital. SSIs were prevalent among women underwent cesarean section; its prevalence was $88.9 \%$ followed by women underwent abdominal hysterectomy and uterine repair; which account $8.3 \%$ and $2.8 \%$ respectively. SSIs were more frequent among women underwent emergency cesarean section (86.1\%) than elective cesarean section (13.9\%). From women who developed SSIs; $61.1 \%$ knew their infection after discharge. The mean day in order to follow up the development postoperative SSIs and the mean number of additional postoperative day of hospital stay due to SSIs were 7.7 (4-18 days) and 13.8(5- 62 days) respectively (Table 3 ).

Socio-demographic determinants of surgical site infection In this study, socio demographic variable had no significant association with SSIs except age, those women age less than nineteen years were three times risk of developing surgical site infection as compare to those age range $20-34(\mathrm{OR}=3.5,95 \% \mathrm{CI} 1.17-10.01)$ (Table 4).

\section{Association of surgical site infection and obstetric variable}

In the present study there was a statistically significant association between gestation age and SSIs, preterm gestation age mothers were four times more likely to develop SSIs as compared to those mothers gestation age was term OR $=4.225$; 95\%CI (1.254-14.238). The duration of labor had statistically significant association with SSIs, those duration of labor more than twenty four

Table 2 Indications for cesarean section in Assilla Teaching Hospital; April, 23, 2015 to September 5, 2015

\begin{tabular}{lll}
\hline Indication & Frequency & Percent \\
\hline NRFHBP & 121 & 31.5 \\
CPD & 42 & 10.9 \\
Protracted /arrest of cervical dilatation & 31 & 8.1 \\
Previous two cesarean section scar & 21 & 5.5 \\
Failed vacuum/forceps & 20 & 5.2 \\
Macrosomia & 20 & 5.2 \\
Failed induction/augmentation $_{\text {Other }}{ }^{\text {a }}$ & 18 & 4.7 \\
Total $^{\text {Totacenta previa, twin A brech, declned VBACS, severe preclamsia }}$ \\
\hline
\end{tabular}

a-placenta previa, twin A breech, declined VBACS, severe pre-eclamsia, poor BPP hours were two times more likely to develop SSIs as compared to those mother duration of labor less than twenty four hours OR $=2.219 ; 95 \%$ CI (1.054-4.670). Similarly, duration of membrane rupture had statistically significant association with SSIs, duration of greater than twelve hours were six times more likely to develop SSIs as compared to those mother duration of membrane rupture less than twelve hours OR $=5.991 ; 95 \%$ CI $(2.757-$ 13.022). The presence of chorioamnionitis had statistically significant association with surgical site infection, those mother who had chorioamnionitis were ten times likely to develop SSIs as compared to those mother who had no chorioamnionitis (OR $=9.743$, 95\%CI 3.077-30.848). Parity and ANC follow up had no statistically significant association with SSIs in this study (Table 5).

\section{Surgical characteristics and surgical site infection}

According to the present study the type of incision had statistically significant association with SSIs. Study subjects underwent vertical skin incision were four times more likely to develop SSIs than transverse skin incision $(\mathrm{OR}=4$, 95\%CI 1.709-13.322). Individuals who had taken ceftriaxone and Metrinadazole were seven times more likely to develop SSIs than Ampicillin (OR $=7.5,95 \%$ CI 3.115 18.004). The pre operation hematocrit had statistically significant association with SSIs, those women who had hematocrit value less than twenty one were six times more likely to develop SSIs as compared to those who had hematocrit value greater than thirty three $(\mathrm{OR}=6.4,95 \%$ C11.021-40.137). Moreover, those women who received transfused blood were six times more likely to develop SSIs as compared to women did not receive transfused blood $(\mathrm{OR}=6.75,95 \% \mathrm{CI}$ 2.471-18.489). Women underwent abdominal hysterectomy were eight times more likely to develop SSIs as compared women underwent cesarean section ( $\mathrm{OR}=7.9,95 \% \mathrm{CI}$ 1.698-36.960). The pre-existing medical illness had also statistically significant association with SSIs; individuals with diabetic mellitus 3.7 times more likely to develop SSIs as compared to those who had no pre-existing medical illness $(\mathrm{OR}=3.7,95 \% \mathrm{CI} 1.112-$ 12.519). The type of anesthesia, duration admission of prophylactic antibiotic, prior cesarean section, circumstance of surgery and intraoperative blood loss had no statistically significant association with SSIs (Table 6).

\section{Multivariate logistic regression analysis of risk factors of surgical site infection}

The outcome of the final backward multiple logistic regression models indicated that preoperative hematocrit, type of antibiotic, type of skin incision,duration of labor, type of operation and gestation age were dropped from the final model. However, age less than 19 years had statistical significant association with SSIs. Study subjects aged less than 19 years were 3.8 times more likely 
Table 3 Outcomes of mothers with SSIs following surgery for delivery in Obstetrics of Assela Teaching Hospital, April, 23, 2015 to September 5, 2015

\begin{tabular}{|c|c|c|c|}
\hline Variables & Category & Frequency $(N=36)$ & Percent \\
\hline \multirow[t]{2}{*}{ The time surgical site infection detected } & Before discharge & 14 & 38.9 \\
\hline & After discharge & 22 & 61.1 \\
\hline \multirow[t]{3}{*}{ Types of surgical site infections detected } & Superficial & 11 & 30.5 \\
\hline & Deep & 23 & 63.8 \\
\hline & Organ /space & 2 & 5.7 \\
\hline \multirow[t]{3}{*}{ Postoperative day SSIs detected } & $\leq 7$ & 19 & 52.7 \\
\hline & $8-14$ & 16 & 44.4 \\
\hline & $15-30$ & 1 & 2.9 \\
\hline \multirow{4}{*}{$\begin{array}{l}\text { Number of additional hospital stay } \\
\text { due to SSIs }\end{array}$} & $\leq 7$ & 7 & 19.4 \\
\hline & $8-14$ & 19 & 52.8 \\
\hline & $15-30$ & 8 & 22.2 \\
\hline & $\geq 31$ & 2 & 5.6 \\
\hline
\end{tabular}

Table 4 Socio-demographic characteristics and surgical wound infection among women having obstetric surgery in Assela Teaching Hospital, April, 23, 2015 to September 5, 2015

\begin{tabular}{|c|c|c|c|c|}
\hline \multirow[t]{2}{*}{ Variable } & \multirow[t]{2}{*}{ Category } & \multicolumn{2}{|l|}{ SSI } & \multirow[t]{2}{*}{ Crude OR(95\%Cl) } \\
\hline & & $\begin{array}{l}\text { Yes } \\
\text { Number (\%) }\end{array}$ & $\begin{array}{l}\text { No } \\
\text { Number (\%) }\end{array}$ & \\
\hline \multirow[t]{3}{*}{ Age } & $\leq 19$ & $5(13.9 \%)$ & $18(52 \%)$ & $3.453(1.18-10.00)$ \\
\hline & $20-34$ & $23(63.9 \%)$ & $286(82.2 \%)$ & 1 \\
\hline & $\geq 35$ & $8(22.2 \%)$ & $44(12.6 \%)$ & $2.26(0.95-5.37)$ \\
\hline \multirow[t]{2}{*}{ Residence } & Urban & $17(47.2 \%)$ & $149(42.8 \%)$ & 1 \\
\hline & Rural & 19(52.8\%) & 199(57.2\%) & $0.837(0.437-1.66)$ \\
\hline \multirow[t]{5}{*}{ Ethnicity } & Oromo & $24(66.7 \%)$ & $235(67.5 \%)$ & 1 \\
\hline & Amhara & $8(22.2 \%)$ & $54(15.5 \%)$ & $1.45(0.618-3.404)$ \\
\hline & Tigrie & $2(5.6 \%)$ & $30(8.6 \%)$ & $0.653(0.147-2.901)$ \\
\hline & Guragie & $1(2.8 \%)$ & $19(5.5 \%)$ & $0.515(0.066-4.020)$ \\
\hline & Other & $1(2.8 \%)$ & $10(2.9 \%)$ & $0.979(0.120-7.981)$ \\
\hline \multirow[t]{4}{*}{ Religion } & Orthodox & 17(47.2\%) & $119(34.2 \%)$ & $1.500(0.729-3.088)$ \\
\hline & Protestant & $3(8.3 \%)$ & $58(16.7 \%)$ & $0.543(0.153-1.931$ \\
\hline & Muslim & $16(44.4 \%)$ & $168(48.3 \%)$ & 1 \\
\hline & Other & 0 & $3(0.9 \%)$ & 0.000 \\
\hline \multirow[t]{4}{*}{ Occupation } & House Wife & $26(72.2 \%)$ & 199(57.2\%) & $2.047(0.815-5.14)$ \\
\hline & Civil Servant & $6(16.7 \%)$ & $94(27 \%)$ & 1 \\
\hline & Farmer & 0 & $3(0.9 \%)$ & $0.000(0.000)$ \\
\hline & Merchant & $4(11.1 \%)$ & $52(14.9 \%)$ & $1.205(0.325-4.465)$ \\
\hline \multirow[t]{5}{*}{ Education Status } & Illiterate & $10(27.8 \%)$ & $67(19.3 \%)$ & $1.727(0.64-4.783)$ \\
\hline & Read and Write only & $2(5.6 \%)$ & $51(14.7 \%)$ & $0.454(0.091-2.270)$ \\
\hline & Grade 1-8 & $7(19.4 \%)$ & $61(17.5 \%)$ & $1.328(0.442-3.985)$ \\
\hline & Grade 9-12 & $10(27.8 \%)$ & $88(25.3 \%)$ & $1.315(0.478-3.617)$ \\
\hline & Above Grade 12 & $7(19.4 \%)$ & $81(23.3 \%)$ & 1 \\
\hline \multirow[t]{3}{*}{ Month Income } & $\leq 1000$ & 17(47.2\%) & 158(45.4\%) & $0.890(0.400-1.983)$ \\
\hline & 1001-3999 & $8(22.2 \%)$ & $99(28.4 \%)$ & $0.669(0.257-1.736)$ \\
\hline & $\geq 4000$ & $11(30.6 \%)$ & $91(26.1 \%)$ & 1 \\
\hline
\end{tabular}


Table 5 Association of surgical site infection and obstetric variable among women having obstetric surgery in Assela Teaching Hospital, April, 23, 2015 to September 5, 2015

\begin{tabular}{|c|c|c|c|c|}
\hline \multirow[t]{2}{*}{ Variable } & \multirow[t]{2}{*}{ Category } & \multicolumn{2}{|l|}{ SSI } & \multirow[t]{2}{*}{ Crude OR(95\%Cl) } \\
\hline & & Yes number (\%) & No number (\%) & \\
\hline \multirow[t]{3}{*}{ Parity } & I & $11(30.6 \%)$ & $101(29 \%)$ & $1.343(0.595-3.034)$ \\
\hline & II-IV & $15(41.7 \%)$ & $185(53.2 \%)$ & 1 \\
\hline & $\geq V$ & $10(27.8 \%)$ & $62(17.8 \%)$ & $1.989(0.85-4.655)$ \\
\hline \multirow[t]{2}{*}{ ANC Follow Up } & Yes & $26(72.2 \%)$ & 284(81.6\%) & 1 \\
\hline & No & $10(27.8 \%)$ & $64(18.4 \%)$ & $1.707(0.784-3.716)$ \\
\hline \multirow[t]{2}{*}{ Gestation Age } & Preterm & $4(11.1 \%)$ & $10(2.9 \%)$ & $4.225(1.254-14.238)$ \\
\hline & Term & $32(88.9 \%)$ & 338(97.1\%) & 1 \\
\hline \multirow[t]{2}{*}{ Duration of Labor } & $\leq 24 \mathrm{~h}$ & $24(66.7 \%)$ & $284(81.6 \%)$ & 1 \\
\hline & $\geq 25 \mathrm{~h}$ & 12(33.3\%) & $64(18.4 \%)$ & $2.219(1.054-4.670)$ \\
\hline \multirow[t]{2}{*}{ Duration Rupture of Membrane } & $\leq 12 \mathrm{~h}$ & $23(63.9 \%)$ & 318(91.4\%) & 1 \\
\hline & $\geq 12 \mathrm{~h}$ & 13(36.1\%) & $30(8.6 \%)$ & $5.991(2.757-13.022)$ \\
\hline \multirow[t]{2}{*}{ Chorioamnionitis } & Yes & $6(16.7 \%)$ & $7(2 \%)$ & $9.743(3.077-30.848)$ \\
\hline & No & $30(83.3 \%)$ & $341(98 \%)$ & 1 \\
\hline \multirow[t]{3}{*}{ Meconium } & Grade III & 12(33.3\%) & $83(23.9 \%)$ & $1.596(0.765-3.33)$ \\
\hline & No & $24(66.7 \%)$ & 265(76.1\%) & 1 \\
\hline & Total & 36 & 348 & \\
\hline
\end{tabular}

to develop SSIs when compared to age 20-34 years. Women who had chorioamnionitis were 9.1 times more likely to develop SSIs than those had no chorioamnionitis. Moreover, duration of rupture membrane greater than $12 \mathrm{~h}$ had also significant association with SSIs. Women who received perioperative transfused blood were 3.8 times more like to develop SSIs as compared to those who did not receive transfused blood. Women with diabetic mellitus were 3.1times more likely to develop SSIs when compared to women who had no any pre-existing medical illness in the present study (Table 7).

\section{Discussion}

SSIs represent a burden to the health care system and patient, mainly attributable to the extended length of stay in hospital and additional treatment required. Consequently, strategies and intervention aimed at reducing the incidence of SSIs could provide cost-saving and improve the efficiency of the health care system. The rate of SSIs were lower when we compared our finding with different studies conducted in African countries but still higher than the studies conducted in developed countries [8, 9, 17-21].

The prevalence of SSIs was 36(9.4\%) in this study. This finding was lower than the study done in Jimma University Specialized Hospital which was $11.4 \%$ [22]. The other studies conducted in Africa, like Nigeria and Tanzanian were $23.6 \%$, and $24 \%$ respectively $[16,23]$. The prevalence of SSI in this study was lower compared to studies done in different hospitals in African countries.
This difference might be due to lost to follow up the development of SSI after discharge.

Majority of the infections were confined to the incision site (94.5\%) and the rest involved the organ/spaces accessed during operation in this study.

With regard to age, age had statistically significant association with SSIs $p=0.04$. This was in line with previous report finding $(\mathrm{OR}=2.1)$ [19]; women age less than 19 years had 3.8 more likely to develop SSIs as compared to age 20-34 years $(\mathrm{OR}=3.81$ 95\% CI 1.05, 13.83). An increased risk of SSIs in younger women had been reported in age less than twenty years $(\mathrm{OR}=1.9)$ [20], but the study conducted in Jimma University Specialized Hospital indicated that age had no significant association with SSIs [8].This might be due to labor abnormality, poor nutrition (such as anemia), decreased immune completeness, urinary tract infection which lead to premature rupture membrane.

In this study prolonged rupture of membrane, greater than twelve hour were predicator of SSIs with $p=0.00$. This was similar with the previous studies $[8,16,17,20$, $21]$; women with prolonged rupture of membrane(greater than twelve hour)had 3.8 times more likely to develop SSIs as compared to duration rupture of membrane less than twelve hour ( $\mathrm{OR}=3.77195 \%$ CI 1.53,9.31). Normally during pregnancy,cervical mucus and amniotic fluid serve as barrier to infection. However if the membrane is ruptured, this protective effect is gradually reduced over as amniotic fluid become no longer sterile. Thus, it was though that the non-sterile amniotic fluid might act as a 
Table 6 Association of surgical site infection and surgical variable among women having obstetric surgery in Assela Teaching Hospital, April, 23, 2015 to September 5, 2015

\begin{tabular}{|c|c|c|c|c|}
\hline \multirow[t]{2}{*}{ Variable } & \multirow[t]{2}{*}{ Category } & \multicolumn{2}{|l|}{ SSI } & \multirow[t]{2}{*}{ Crude OR(95\%Cl) } \\
\hline & & $\begin{array}{l}\text { Yes } \\
\text { Number (\%) }\end{array}$ & $\begin{array}{l}\text { No } \\
\text { Number (\%) }\end{array}$ & \\
\hline \multirow[t]{2}{*}{ Type of Anesthesia } & Spinal & $30(83.3 \%)$ & $306(87.9 \%)$ & 1 \\
\hline & General & $6(16.7 \%)$ & $42(12.1 \%)$ & $1.457(0.573,3.708)$ \\
\hline \multirow[t]{2}{*}{ Prior Cesarean section scar } & Yes & $4(11.1 \%)$ & $38(10.9 \%)$ & $1.020(0.342,3.041)$ \\
\hline & No & $32(88.9 \%)$ & $310(89.1 \%)$ & 1 \\
\hline \multirow[t]{2}{*}{ Circumstance of Surgery } & Emergency & $31(86.1 \%)$ & $313(89.9 \%)$ & $0.693(0.253,1.898)$ \\
\hline & Elective & $5(13.9 \%)$ & $35(10.1 \%)$ & 1 \\
\hline \multirow[t]{3}{*}{ Type of Operation } & Cesarean section & $32(88.9 \%)$ & $338(97.1 \%)$ & 1 \\
\hline & Abdominal hysterectomy & $3(8.3 \%)$ & $6(1.7 \%)$ & $7.922(1.698,36.960)$ \\
\hline & Uterine Repair & $1(2.8 \%)$ & $4(1.1 \%)$ & $2.641(0.286,24.340)$ \\
\hline \multirow[t]{2}{*}{ Type of Skin Incision } & Vertical Incisions & $6(16.7 \%)$ & $14(4 \%)$ & 4.771(1.709,13.322) \\
\hline & Transverse Incision & $30(83.3 \%)$ & $334(96 \%)$ & 1 \\
\hline \multirow[t]{2}{*}{ Time of antibiotic admission } & With 30 min before surgery & $22(61.1 \%)$ & $252(72.4 \%)$ & 1 \\
\hline & After operation & 14(38.9\%) & $96(27.6 \%)$ & $0.662(0.138,2.624)$ \\
\hline \multirow[t]{2}{*}{ Type of antibiotic } & Ampicillin & $26(72.2 \%)$ & $331(95.1 \%)$ & 1 \\
\hline & Ceftriaxone \&Metrindazole & $10(27.8 \%)$ & $17(4.9 \%)$ & $7.489(3.115,18.004)$ \\
\hline \multirow[t]{2}{*}{ Intraoperative blood loss } & Less than 1000 & $35(97.2 \%)$ & $344(98.9 \%)$ & 1 \\
\hline & Greater than 1000 & $1(2.8 \%)$ & $4(1.1 \%)$ & $2.457(0.267,22.595)$ \\
\hline \multirow[t]{2}{*}{ Perioperative Blood Transfusion } & Yes & $7(19.4 \%)$ & $12(3.4 \%)$ & $6.759(2.471,18.489)$ \\
\hline & No & $29(80.6 \%)$ & $336(96.6 \%)$ & 1 \\
\hline \multirow[t]{6}{*}{ Acute /Chronic medical problem } & UTI & 0 & $12(3.4 \%)$ & 0.000 \\
\hline & Pneumonia & $1(2.8 \%)$ & $8(2.3 \%)$ & $1.282(0.155,10.642$ \\
\hline & HIV/AIDS & $1(2.8 \%)$ & $3(0.9 \%)$ & $3.420(0.344,34.021$ \\
\hline & Diabetes mellitus & $4(11.1 \%)$ & $11(3.2 \%)$ & $3.731(1.112,12.519)$ \\
\hline & Other & $3(8.3 \%)$ & $37(10.6 \%)$ & $0.832(0.240,2.878)$ \\
\hline & No known illness & $27(75 \%)$ & $277(79.6 \%)$ & 1 \\
\hline
\end{tabular}

transport medium by which bacteria got the chance to contact with uterus and skin incision and this might resulted in chorioamnionitis.

In our study chorioamnionitis had statistically significant association with SSIs with $p=0.00$; women with chorioamnionitis had 9.7 times more likely to develop SSIs when compared to those women who had no chorioamnionitis (OR $=9.74 .95 \%$ CI 2.35, 34.83), and this had been observed in the previous studies [1, 8, 16-18, 21-26]. The gestational age andduration of labor had no association with SSIs in this study, this was in line with previous study findings $[1-4,7,8,12,13,16-18,21-28]$. In contrast to previous study done in Jimma University Specialized Hospital [8], no significant association was observed among ANC follow up and surgical site infection in this study.

Intake of Preoperative transfused blood was predictor of SSIs with $p=0.00$; women who had received preoperative blood transfusion were 7.7 times more likely to develop SSIs as compared to those who had no received blood transfusion (OR $=7.7895 \%$ CI 2.37,25.54), and this had been observed in the previous study [20]. However there was no scientific basis for withholding necessary blood products from surgical patients as a means of either incisional or organ/space SSI risk reduction.

In our study diabetes mellitus was found to be predicator of SSIs with $p=0.01$; women with diabetic mellitus had 5.4 times more likely to develop SSIs as compared to those with non-diabetic mellitus and this was in line with the previous study [21]. This could be due to abnormalities in cell-mediated immunity and phagocyte function associated with hyperglycemia, as well as diminished vascular supply to tissue and increased rate of colonization of S. aureus in the skin folds.

\section{Conclusions}

In the present study the rates of SSIs was high. Women who were age less than 19, prolonged rupture of membrane, chorioamnionitis, preoperative blood transfusion 
Table 7 Crude and adjusted associations of risk factors surgical site infection among women having obstetric surgery in Assela Teaching Hospital, April, 23, 2015 to September 5, 2015

\begin{tabular}{|c|c|c|c|c|c|}
\hline \multirow[t]{2}{*}{ Variable } & \multirow[t]{2}{*}{ Category } & \multicolumn{2}{|l|}{ SSI } & \multirow[t]{2}{*}{$\operatorname{COR}(95 \% \mathrm{Cl})$} & \multirow[t]{2}{*}{ AOR $(95 \% \mathrm{Cl})$} \\
\hline & & $\begin{array}{l}\text { Yes } \\
\text { Number (\%) }\end{array}$ & $\begin{array}{l}\text { No } \\
\text { Number (\%) }\end{array}$ & & \\
\hline \multirow[t]{3}{*}{ Age } & $\leq 19$ & $5(13.9 \%)$ & $18(52 \%)$ & $3.453(1.18,10.00)$ & $3.81(1.05,13.83)$ \\
\hline & $20-34$ & $23(63.9 \%)$ & $286(82.2 \%)$ & 1.0 & 1.0 \\
\hline & $\geq 35$ & $8(22.2 \%)$ & $44(12.6 \%)$ & $2.26(0.95-5.37)$ & $2.13(0.79,5.73)$ \\
\hline \multirow[t]{2}{*}{ Duration Rupture of Membrane } & $\leq 12 \mathrm{~h}$ & 23(63.9\%) & $318(91.4 \%)$ & 1.0 & 1.0 \\
\hline & $\geq 12 \mathrm{~h}$ & 13(36.1\%) & $30(8.6 \%)$ & $5.99(2.75-13.022)$ & $3.77(1.53,9.31)$ \\
\hline \multirow[t]{2}{*}{ Chorioamnionitis } & Yes & $6(16.7 \%)$ & $7(2 \%)$ & $9.74(3.08-30.84)$ & $9.05(2.35,34.83)$ \\
\hline & No & $30(83.3 \%)$ & $341(98 \%)$ & 1.0 & 1.0 \\
\hline \multirow[t]{2}{*}{ Perioperative Blood Transfusion } & Yes & $7(19.4 \%)$ & $12(3.4 \%)$ & $6.76(2.47,8.49)$ & $7.78(2.37,25.54)$ \\
\hline & No & $29(80.6 \%)$ & $336(96.6 \%)$ & 1 & 1.0 \\
\hline \multirow[t]{6}{*}{ Acute /Chronic medical problem } & UTI & 0 & $12(3.4 \%)$ & 0.000 & 0.000 \\
\hline & Pneumonia & $1(2.8 \%)$ & $8(2.3 \%)$ & $1.28(0.15,10.64)$ & $0.50(0.02,9.18)$ \\
\hline & HIV/AIDS & $1(2.8 \%)$ & $3(0.9 \%)$ & $3.42(0.34,34.02)$ & $3.14(0.25,39.0)$ \\
\hline & Diabetes mellitus & $4(11.1 \%)$ & $11(3.2 \%)$ & $3.73(1.11,12.52)$ & $5.41(1.45,20.11)$ \\
\hline & Other & $3(8.3 \%)$ & $37(10.6 \%)$ & $0.83(0.24,2.88)$ & $0.46(0.11,1.94)$ \\
\hline & No & $27(75 \%)$ & $277(79.6 \%)$ & 1.0 & 1.0 \\
\hline
\end{tabular}

and diabetes mellitus had been found predictors of SSIs. These five independent risk factors should be considered when establishing strategies for SSIs prevention and surveillance. Therefore,

Obstetric ward of Assela teaching referral hospital are encouraged to use properly the WHO surgical safety checklist and examine how to sensibly integrate these essential safety steps into their normal operative workflow. Prophylactic antibiotic administration should be provided within one hour before the surgical incision or within two hours if the patient is receiving vancomycin or floroquinolones.

Health information should be provided on ANC follow up, postnatal follow up and early marriage.

This study could be subjected to cross sectional study design bias and it was taken as the limitation of this study.

\section{Abbreviations}

CDC's: Centers for Disease Control and Prevention's; NHSN: National Healthcare Safety Network; SSIs: Surgical Site Infections

\section{Acknowledgments}

We would like to express our heartfelt thanks to Assela Teaching Hospital Obstetric ward members for their unlimited support. We would also like to extend our deepest gratitude to all study participants.

\section{Funding}

The authors received no specific funding for this study.
Availability of data and materials

Data is not available for online access but interested readers can communicate with the corresponding author Antehun Alemayehu at Antehunalemayehu@gmail.com.

\section{Authors' contributions}

TM, TA, TY and AA were involved in conceptualization, designing the study, writing proposal, Formal analysis, Project administration and interpretation of data. All authors read and approved the final manuscript.

\section{Competing interest}

We declared no financial, personal or professional competing interests influenced this paper.

\section{Ethics approval and consent to participate}

Adama Hospital Medical College granted ethical approval letter for the study with a reference number 006/2015 and letter of support was received from Assela teaching hospital ethical review committee. Moreover, written consent was obtained from the study subjects while data were collected from the study subjects. Moreover, the rights of the respondents to withdraw (not to participate) were respected. In addition to this, names of participants were not used in the study and information's obtained from patients were held confidentially.

\section{Consent for publication}

Not applicable.

\section{Publisher's Note}

Springer Nature remains neutral with regard to jurisdictional claims in published maps and institutional affiliations.

\section{Author details}

'Department of General Surgery at Bale Ginnir Hospital, Ginnir, Ethiopia. ²Department of Public Health, Adama Hospital Medical College, Adama, Ethiopia. ${ }^{3}$ Department of Nursing, College of Health Science and Medicine, Wolaita Sodo University, Wolaita Sodo, Ethiopia. ${ }^{4}$ Department of Medical 
Laboratory, School of Medicine, College of Health sciences and Medicine, Wolaita Sodo University, P.O. Box: 138, Wolaita Sodo, Ethiopia.

\section{Received: 13 July 2017 Accepted: 4 September 2017}

Published online: 19 September 2017

\section{References}

1. Kotiso B, Assefa A. Surgical wound infection in a teaching hospital in Ethiopia. East Afr J. 1998;75:402-5.

2. Van Beneden CA, Hicks Lauri A, Riley Laura E, Jay S. Provider knowledge, attitude, practices regarding obstetrics and post surgical gynecologic infections. Infect Dis Obstet Gynecol. 2007;2007:90189. doi: 10.1155/2007/ 90189.

3. Ado C, Tertuliano A. George Maria. SSI in university hospital in north east Brazil. Brazil J Infect Dis. 2005:9(4):26-30

4. Daniel A, Tesfahunegne Z. Hospital acquired surgical site and catheter related urinary tract infections among patients admitted in Mekele hospital, Mekele, Tigray, Ethiopia. 2008. Apr 23, AAU libraries electronic thesis and dissertation.

5. WHO, UNICEF, UNFPA and World Bank. Estimates of maternal mortality: a report by WHO, UNICEF, UNFPA and World Bank. Geneva: WHO; 2005.

6. Mulat T. Wound infection in Tikur Anbessa hospital, surgical department Ethiopian Med J. 2005;43(3):167-74.

7. Addis Ababa, Ethiopia and Calverton, Maryland, USA: central statistical agency and Marco, author. Ethiopia Demographic and health survey on nutrition in pregnancy; 2005. p. 163-4.

8. Amoran $\mathrm{OE}$, Sogebi $\mathrm{AO}$, Fatigues $\mathrm{OM}$. Rates and risk factors associated with surgical site infections in a tertiary Care Center in South-Western Nigeria. International Journal of TROPICAL DISEASE \& Health. 2013;3(1):25-36.

9. Morgan AJ, Horan TC, Pearson ML, Silver LC, Jarvis WR. The hospital infection control practices advisory committee: a guideline for prevention of surgical site infection. Infect Control Hosp Epidemiol. 1999;20(4):247-78.

10. Horan TC, Gaynes RP, Martone WJ, Tarvis WR, Emori TG. CDC definition of nosocomial surgical site infection: a modification of CDC definition of surgical wound infection. Infect Control Hosp Epidemiol. 1992;13(10):606-8.

11. Ehrenkranz NJ, Richter El, Phillips PM, Shultz JM. An apparent excess of operative site infections: analyses to evaluate false positive diagnosis. Infect Control Hosp Epidemiol. 1995;16(12):712-6.

12. Taylor G, Mckenzie M, Kirkland T, Wiens R. Effect of surgeon's diagnosis on surgical wound infection rates. Am J Infection Control. 1990;18(5): 295-9.

13. Raka L, Zounman D. Prevalence of nosocomial infections in high risk units in the university clinical center of Kosovo. Infect Control Hosp Epidemiol. 2006;27(4):421-3.

14. Rock John A, Jones HW. Te Linde's operative gynecology. 10th ed; 2008

15. Cuver DH, Horan TC, Gynes RP, et al. Surgical Wound infection rates by wound class, operative procedure, and patient risk index NNIS system. Am J Med. 1991;91(suppl B):152-57.

16. Amenu D, Belachew T, Araya F. Surgical site infection rate and risk factors among obstetric cases of Jimma University specialized hospital, Southwest Ethiopia. Ethiop J Health Sci. 2011;21(2):91-100.

17. Tan JT, Coleman K, Norris S, Metz L. Surgical site infection in china. J Obstet Gynecology Res. 2012;38(3):509-15.

18. Johan Wiley and Sons. Risk factor for surgical site infection after cesarean section in England royal college of obstetrics and gynecology hospital. Infect Control Hosp Epidemiol. 2014;29:6.

19. Farret TCF, Dallé J, da Silva Monteiro V. Risk factors for surgical site infection following cesarean section in a Brazilian Women's hospital. Brazil J Infect Dis. 2015;19(2):113-7.

20. Ansar A. Surgical site infection, Cesarean section, wound infection.Journal of surgery Pakistan(international). 2013;18(2).

21. Haley RW, Culver DH, Morgan WM, White JW, Emori TG, Hooton TM. Identifying patients at high risk of surgical wound infection. A simple multivariate index of patient susceptibility and wound contamination. Am J Epidemiol. 1985;121:206-15.

22. Olsen MA, Butler AM, Willers DM, Devkota P, Gross GA, Fraser VJ. Risk factors for surgical site infection after low transverse cesarean section. Infect Control Hosp Epidemiol. 2008;29:6.

23. Jan F, Christoph H, Isaac S, Patience K. Risk factors for SSI in a Tanzanian district hospital: a challenge for the traditional National Nosocomial
Infection Surveillance System Index. Infect Control Hosp Epidemiol. 2006; 27(12):1401-4.

24. Vegas AA, Jodan VM, Garcia ML. Nosocomial infection in surgery wards: a controlled study of increased duration of hospital stay and direct cost of hospitalization. Eur J Epidemiol. 1993;9(5):504-10.

25. Garner JS. The CDC hospital infection control practices advisory committee. Am J Infection Control. 1993:21:160-2.

26. Piper JM, Newton ER, Berkus MD, Peairs WA. Meconium: a marker for peripartum infection. Obstet Gynecol. 1998;91(5 Pt 1):741-5.

27. SHEA, APIC, CDC, SIS. Consensus paper on the surveillance of surgical wound infections. Infect Control Hosp Epidemiol. 1992;13(10):599-605.

28. Larsen John W, Hager W, David LCH, Udo H. Guideline for the diagnosis, treatment and prevention of post operative infections. Infections Disease Obs/Gyn. 2003;11:65-70.

\section{Submit your next manuscript to BioMed Central and we will help you at every step:}

- We accept pre-submission inquiries

- Our selector tool helps you to find the most relevant journal

- We provide round the clock customer support

- Convenient online submission

- Thorough peer review

- Inclusion in PubMed and all major indexing services

- Maximum visibility for your research

Submit your manuscript at www.biomedcentral.com/submit
Biomed Central 